\title{
ANALISIS PENGARUH TINGKAT LABA BERSIH DAN UKURAN PERUSAHAAAN TERHADAP KOEFISIEN RESPON LABA PADA PERUSAHAAN MANUFAKTUR DI BEI TAHUN 2013 - 2016
}

\author{
Reynaldo Soeiswanto Soei ${ }^{1}$, Grace B. Nangoi ${ }^{2}$, Meily Y. B. Kalalo ${ }^{3}$ \\ 1,2,3 Jurusan Akuntansi, Fakultas Ekonomi dan Bisnis Universitas Sam Ratulangi, J1. Kampus Bahu, Manado, \\ 95115, Indonesia \\ E-mail : reynaldosoei@gmail.com
}

\begin{abstract}
The earnings response coefficient can be indicated as the ability of the profit information to respond to the market. In other words, reported earnings have the power of response. The purpose of this research was to analyze the influence of net profit rate and size firm on earnings response coefficient. The population of this research is manufacturing companies listed on Indonesia Stock Exchange in period 2013-2016 as many as 149 companies. From the population of 149 manufacturing companies listed on Indonesian Stock Exchange, researchers used a sample of 36 manufacturing companies. The independent variables are net profit rate and size firm while the dependent variable is earnings response coefficient. The analysis method of this research are quantitative descriptive statistics and multiple linear regression analysis. The result of normality test showed that the independent variabel and the dependent variabel are not normally distributed. When the data is not normally distributed, the thing to do is transform the research data and test the normality again. The result of this research showed that net profit rate has positive and not significant effect on earnings response coefficient, size firm has positive and significant effect on earnings response coefficient, and also net profit rate and size firm have significant result on earnings response coefficient.
\end{abstract}

Keywords : Net Profit Rate, Size Firm, Earnings Response Coefficient

\section{PENDAHULUAN}

Perkembangan dunia yang pesat saat ini tidak terlepas dari peran sentral investasi sebab investasi membuka peluang bagi temuan-temuan penting bagi kehidupan manusia.Dalam pengambilan keputusan investasi di pasar modal investor mempertimbangkan banyak hal dan membutuhkan informasi untuk pengambilan keputusan. Informasi yang dibutuhkan tersebut bisa dilihat dari laporan keuangan. Laporan keuangan merupakan alat yang sangat penting untuk mendapatkan informasi sehubungan dengan posisi keuangan dan kinerja perusahaan. Laporan keuangan tersebut terdiri dari neraca, laporan laba rugi, laporan perubahan modal, laporan arus kas, dan catatan atas laporan keuangan. Salah satu unsur laporan keuangan yang paling banyak diperhatikan dan dinanti-nantikan oleh para investor dan kreditor terhadap informasinya adalah laporan laba rugi.

Laporan laba rugi merupakan suatu laporan yang berisi informasi mengenai laba (earnings) yang dicapai oleh perusahaan dalam suatu periode tersebut. Laporan laba rugi merupakan laporan utama mengenai kinerja dari suatu perusahaan selama periode tertentu. Laporan laba rugi memuat banyak angka laba yaitu laba kotor, laba operasi, dan laba bersih. Agar dapat dijadikan sebagai alat pengambil keputusan yang andal, laporan laba rugi harus memiliki informasi yang bernilai. Informasi laba diterbitkan oleh manajemen yang lebih mengetahui kondisi di dalam perusahaan. Informasi laba dikatakan bernilai jika publikasi atas informasi tersebut menyebabkan bergeraknya reaksi pasar.

Laba (earning) merupakan ukuran kinerja atau keberhasilan bagi suatu perusahaan dan digunakan oleh investor dan kreditur untuk pertimbangan pengambilan keputusan melakukan investasi atau memberikan tambahan kredit. Laba terdiri atas 3 bagian yaitu laba kotor, laba operasi, dan laba bersih. Salah satu informasi yang diperlukan investor maupun 
kreditur adalah laba bersih. Tingkat laba bersih merupakan selisih antara laba bersih pada tahun sekarang dan laba bersih pada tahun sebelumnya. Jika tingkat laba bersih dari suatu perusahaan pada tahun ke tahun mengalami kenaikan secara bertahap, maka para investor semakin berniat untuk melakukan investasi di perusahaan tersebut. Jika tingkat laba bersih dari suatu perusahaan pada tahun ke tahun mengalami penurunan secara bertahap, maka para investor semakin sedikit untuk melakukan investasi di perusahaan tersebut.

Ukuran perusahaan merupakan proksi dari keinformatifan harga. Semakin besar suatu perusahaan maka semakin banyak informasi publik yang tersedia mengenai perusahaan tersebut, begitu pula dengan sebaliknya. Dengan banyaknya informasi yang tersedia mengenai perusahaan besar maka investor akan lebih mudah untuk menginterpretasi informasi sehingga dapat menurunkan ketidakpastian arus kas masa depan perusahaan dan akan lebih memiliki kepercayaan pada perusahaan besar. Koefisien respon laba (ERC) adalah ukuran besaran abnormal return suatu saham sebagai respon terhadap komponen laba abnormal (unexpected earnings) yang dilaporkan oleh perusahaan yang mengeluarkan saham tersebut. ERC merupakan pengaruh laba abnormal (unexpected earnings) terhadap CAR (cumulative abnormal return), yang ditunjukkan melalui slope coefficient dalam regresi abnormal return saham dengan unexpected earnings. Hal ini menunjukkan bahwa ERC adalah reaksi CAR terhadap laba yang diumumkan oleh perusahaan. Kuatnya reaksi pasar terhadap informasi laba tercermin dari tingginya koefisien respon laba (Earnings Response Coefficient) atau ERC.

\section{TINJAUAN PUSTAKA}

\subsection{Koefisien Respon Laba}

Kualitas laba dapat diindikasikan sebagai kemampuan informasi laba memberikan respon kepada pasar. Dengan kata lain, laba yang dilaporkan memiliki kekuatan respon (power of response). Kuatnya reaksi pasar terhadap informasi laba yang tercermin dari tingginya earnings response coefficients (ERC), menunjukkan laba yang dilaporkan berkualitas. Dan tinggi rendahnya Earning Response Coefficient (ERC) sangat ditentukan kekuatan responsive yang tercermin dari informasi ( good/bad news) yang terkandung dalam laba (Paramita, 2012:107).

\subsection{Laba Bersih}

Tujuan dari setiap perusahaan adalah memaksimumkan keuntungan. Keuntungan atau laba (profit) adalah selisih dari pendapatan di atas biaya $\neg$ biayanya dalam jangka waktu (periode) tertentu. Laba bersih yang terkandung dalam laporan laba rugi merupakan komponen yang sangat berpengaruh pada saham. Hal ini dikarenakan saham dipengaruhi oleh kinerja keuangan suatu emiten. Jika laba perusahaan meningkat, maka saham perusahaan tersebut pun akan naik, sebaliknya jika perusahaan merugi, maka saham perusahaan tersebut akan turun. (Harnanto, dikutip dalam Adiwiratama, 2012: 8).

\subsection{Ukuran Perusahaan}

Ukuran Perusahaan didefinisikan sebagai penentuan besaran, dimensi, atau kapasitas dari suatu perusahaan, sebagai penentuan sebuah perusahaan besar, atau kecil dapat dilihat dari nilai total aktiva, penjualan bersih, dan kapitalisasi pasar (Daniel, 2013: 7).

Biasanya perusahaan yang besar mempunyai kemampuan lebih baik dalam menghadapi risiko dan mengembangkan operasi perusahaan. Hal ini disebabkan karena perusahaan besar lebih menganekaragamkan lini produknya atau bidang usahanya, yang bertujuan untuk mendiversifikasikan risiko dalam menjalankan usahanya. Maksudnya yaitu dengan risiko yang minimal akan mendapatkan keuntungan, atau dengan risiko tertentu untuk memperoleh keuntungan investasi yang maksimal (Adiwiratama, 2012: 9). 


\subsection{Hipotesis}

Pada bagian ini akan dijelaskan mengenai pengembangan hipotesis-hipotesis penelitian dengan dasar penelitian-penelitian terdahulu. Terdapat tiga hipotesis penelitian yang akan dijabarkan sebagai berikut.

H1: Tingkat laba bersih berpengaruh signifikan terhadap koefisien respon laba.

$\mathrm{H} 2$ : Ukuran perusahaan berpengaruh signifikan terhadap koefisien respon laba.

H3: Tingkat laba bersih dan ukuran perusahaan berpengaruh signifikan terhadap koefisien respon laba.

\section{METODE PENELITIAN}

\subsection{Jenis dan sumber data}

Penelitian ini menganalisis data kuantitatif, yaitu data yang berbentuk angka diperoleh dari laporan keuangan berupa nilai laba bersih, aktiva, harga saham tiap perusahaan, dan indeks harga saham gabungan. Sumber data dalam penelitian ini adalah data sekunder yang bersumber dari dokumentasi perusahaan, yaitu laporan keuangan tahunan dan annual report perusahaan manufaktur yang terdaftar di Bursa Efek Indonesia (BEI).

\subsection{Sampel dan teknik pengambilan sampel}

Sampel yaitu sebagian dari populasi atau dalam istilah matematik dapat disebut sebagai himpunan bagian atas atau subset dari populasi. Metode sampel yang diterapkan adalah metode purposive sampling yang merupakan teknik pengambilan data secara non probabilitas (nonprobability sampling). Purposive sampling yaitu pemilihan sampel secara tidak acakyang diperoleh dengan menggunakan pertimbangan tertentu. Dalam penelitian ini perusahaan diseleksi berdasarkan kriteria-kriteria sebagai berikut.

1. Perusahaan tersebut sudah terdaftar secara konsisten dalam Bursa Efek Indonesia atau dari tahun 2013- 2016.

2. Perusahaan tersebut menyajikan laporan keuangan dalam rupiah.

3. Perusahaan menerbitkan laporan keuangan selama 4 tahun secara berturut-turut dari 2013-2016 dan dapat diperoleh secara lengkap.

4. Perusahaan harus melaporkan laba positif.

5. Perusahaan harus melaporkan laporan keuangan per 1 Januari - 31 Desember.

\subsection{Metode analisis}

Analisis data berisi pengujian data perusahaan manufaktur yang terdaftar di Bursa Efek Indonesia (BEI). Analisis data yang digunakan dalam penelitian ini yaitu Uji Regresi Linear Berganda. Uji Regresi Linear Berganda yaitu adalah hubungan secara linear antara dua atau lebih variabel independen (X) dengan variabel dependen (Y). Pengujian regresi linear berganda di awali dengan Uji Asumsi Klasik. Dengan adanya pengujian ini diharapkan agar model regresi yang diperoleh dapat dipertanggungjawabkan. Oleh karena itu, perlu dilakukan uji asumsi klasik yang terdiri dari Uji Normalitas, Uji Multikolinearitas, Uji Heteroskedastisitas, dan Uji Autokorelasi sebelum melakukan Uji Regresi dan Uji Hipotesis.

\section{HASIL ANALISIS DAN PEMBAHASAN}

\subsection{Hasil analisis}

\subsubsection{Uji Asumsi Klasik}

Pengujian asumsi klasik dalam penelitian ini terdiri dari uji normalitas, uji multikolinearitas, uji heteroskedastisitas, dan uji autokorelasi. Pengujian asumsi klasik diperlukan untuk mengetahui apakah hasil estimasi regresi yang dilakukan benar-benar bebas dari adanya gejala distribusi tidak normal, gejala multikolinearitas, gejala heteroskedastisitas, dan gejala autokorelasi.

a. Uji Normalitas

Uji normalitas dilakukan untuk mengetahui apakah model regresi, variabel dependen 
dan independen atau keduanya berdistribusi normal atau tidak. Model regresi yang baik adalah memiliki distribusi data normal atau mendekati normal. Dalam penelitian ini, uji normalitas menggunakan Uji Kolmogorov Smirnov. Hasil dari pengujian normalitas adalah sebagai berikut.

\begin{tabular}{|c|c|c|}
\hline & & $\begin{array}{l}\text { Unstandardized } \\
\text { Residual }\end{array}$ \\
\hline \multicolumn{2}{|l|}{$\mathrm{N}$} & 41 \\
\hline & Mean & $0 \mathrm{E}-7$ \\
\hline \multirow[t]{3}{*}{ Normal Parameters ${ }^{\mathrm{a}, \mathrm{b}}$} & Std. & 1,07192509 \\
\hline & Deviation & \\
\hline & Absolute & ,068 \\
\hline \multirow[t]{2}{*}{ Most Extreme Differences } & Positive & ,067 \\
\hline & Negative &,- 068 \\
\hline Kolmogorov-Smirnov Z & & 433 \\
\hline Asymp. Sig. (2-tailed) & & ,992 \\
\hline
\end{tabular}

a. Test distribution is Normal.

b. Calculated from data.

Sumber: Data diolah peneliti

Berdasarkan hasil uji normalitas dapat disimpulkan bahwa distribusi residual pada penelitian ini adalah distribusi normal, karena nilai signifikan yang dihasilkan lebih besar dari 0,05 sehingga dengan sendirinya variabel earnings response coefficient (ERC), net profit rate (NPR), dan ukuran perusahaan juga berdistribusi normal.

b. Uji Multikolinearitas

Uji multikolinieritas dilakukan untuk menguji apakah model regresi memiliki korelasi antara variabel bebas. Cara untuk mendeteksi adanya multikolonieritas adalah dengan melihat nilai tolerance dan nilai Variance Inflation Factor (VIF). Kedua ukuran ini menunjukkan setiap variabel independen mana yang dijelaskan oleh variabel independen lainnya. Nilai tolerance mengukur variabilitas variabel independen lainnya yang tidak dijelaskan oleh variabel independen lainnya. Menurut Santoso (2016: 361), suatu model regresi dikatakan bebas dari multikolinearitas jika mempunyai nilai VIF di sekitar angka 1 dan mempunyai angka tolerance mendekati 1 dimana tolerance $=1 / \mathrm{VIF}$ atau bisa juga VIF $=1 /$ tolerance . Hasil dari pengujian multikolinearitas adalah sebagai berikut.

\begin{tabular}{|c|c|c|}
\hline Variabel Bebas & Tolerance & VIF \\
\hline NPR & 0,997 & 1,003 \\
\hline SIZE & 0,997 & 1,003 \\
\hline
\end{tabular}

Sumber: Data diolah peneliti

Dari hasil uji multikolinearitas dapat diketahui nilai variance inflation factor (VIF) terhadap variabel net profit rate (NPR) dan ukuran perusahaan (SIZE) memiliki nilai VIF yang sama yaitu sebesar 1,003 dimana nilai VIF tersebut lebih kecil dari 10 dan di sekitar angka 1, sehingga dapat disimpulkan bahwa antarvariabel bebas tidak terjadi persoalan multikolinearitas sehingga asumsi klasik multikolinearitas terpenuhi.

c. Uji Heteroskedastisitas

Heteroskedastisitas adalah adanya ketidaksamaan varian dari residual untuk semua pengamatan pada model regresi (Basuki dan Prawoto, 2016: 63). Model regresi yang baik yaitu homoskedastisitas atau tidak terjadi heteroskedastisitas. Dalam penelitian ini untuk mendeteksi heteroskedastisitas menggunakan metode Rank Spearman Correlation yaitu dengan meregresikan variabel-variabel bebas dengan variabel pengganggu (residual). Hasil dari uji Rank Spearman Correlation adalah sebagai berikut. 


\begin{tabular}{|c|c|c|}
\hline Variabel Bebas & $\begin{array}{c}\text { Koefisien Korelasi } \\
\text { Rank Spearman }\end{array}$ & $\begin{array}{c}\text { Tingkat } \\
\text { Signifikansi }\end{array}$ \\
\hline NPR & $-0,056$ & 0,730 \\
\hline SIZE & $-0,082$ & 0,609 \\
\hline
\end{tabular}

Sumber: Data diolah peneliti

Dari hasil uji diatas dapat diketahui bahwa variabel net profit rate (NPR) memiliki tingkat signifikansi sebesar 0,730 dimana tingkat signifikansi tersebut lebih besar dari 0,05 dan variabel ukuran perusahaan (SIZE) memiliki tingkat signifikansi sebesar 0,609 dimana tingkat signifikansi tersebut lebih besar dari 0,05. Berdasarkan tabel 4.4 dapat disimpulkan bahwa model regresi terhadap variabel ROI dan variabel SIZE tidak terjadi heteroskedastisitas.

d. Uji Autokorelasi

Uji autokorelasi bertujuan untuk mengetahui apakah dalam model regresi linier ada korelasi antara periode sekarang dengan periode sebelumnya. Persyaratan yang harus dipenuhi adalah tidak adanya autokorelasi dalam model regresi.

$\mathrm{H}_{0} \quad$ : tidak terjadi autokorelasi

$\mathrm{H}_{\mathrm{a}} \quad$ : terjadi autokorelasi

Masalah autokorelasi diuji melalui tabel Durbin Watson dengan menggunakan tabel batas bawah (dL) dan batas atas (dU) untuk mengetahui daerah autokorelasi dari nilai Durbin Watson. Dalam penelitian ini, hasil uji autokorelasi adalah sebagai berikut.

\begin{tabular}{|c|r|r|r|r|r|}
\hline $\begin{array}{c}\text { Mode } \\
1\end{array}$ & R & R Square & $\begin{array}{c}\text { Adjusted R } \\
\text { Square }\end{array}$ & $\begin{array}{c}\text { Std. Error of } \\
\text { the Estimate }\end{array}$ & $\begin{array}{c}\text { Durbin- } \\
\text { Watson }\end{array}$ \\
\hline 1 &, $657^{\mathrm{a}}$ &, 432 &, 402 & 1,09977 & 2,226 \\
\hline
\end{tabular}

a. Predictors: (Constant), Ln_SIZE, Ln_NPR

b. Dependent Variable: Ln_ERC

Sumber: Data diolah peneliti

Hasil penelitian di atas didapat nilai DW dari model regresi adalah 2,226, sedangkan dari tabel DW dengan signifikan 0,05 dan $\mathrm{n}=41$ serta $\mathrm{k}=2$ diperoleh nilai $\mathrm{dL}$ sebesar 1,3992 dan dU sebesar 1,6031. Karena nilai DW $(2,226)$ berada pada daerah di antara dU $(1,6031)$ dan 4-dU (2,3969), atau dU < DW < 4-dU $(1,6031<2,226<2,3969)$, maka menerima $\mathrm{H}_{0}$ dan menolak $\mathrm{H}_{\mathrm{a}}$, sehingga dapat disimpulkan bahwa tidak terjadi autokorelasi pada data dalam pengamatan.

\subsubsection{Persamaan Regresi Linear Berganda}

Uji regresi linear berganda dimaksudkan untuk mengetahui besarnya pengaruh secara kuantitatif dari perubahan $\mathrm{X}$ terhadap perubahan $\mathrm{Y}$, apakah positif atau negatif, dan memperkirakan atau meramalkan nilai $\mathrm{Y}$ bila variabel $\mathrm{X}$ yang berkorelasi dengan $\mathrm{Y}$ mengalami kenaikan atau penurunan. Pada penelitian ini menggunakan tingkat laba bersih yang di-proxy-kan dengan net profit rate (NPR) dan ukuran perusahaan yang di-proxy-kan dengan logaritma natural dari total aktiva dalam perusahaan sebagai variabel independen serta koefisien respon laba yang di-proxy-kan dengan regresi antara cumulative abnormal return (CAR) dan unexpected earnings (UE) sebagai variabel dependen.

\begin{tabular}{|l|c|}
\hline \multicolumn{1}{|c|}{ Variabel Bebas } & Koefisien Regresi \\
\hline (Constant) & $-2,679$ \\
NPR & 0,171 \\
SIZE & 0,249 \\
\hline
\end{tabular}

Sumber: Data diolah peneliti 
Berdasarkan hasil uji regresi di atas, dapat diketahui persamaan regresi linear yang terbentuk sebagai berikut:

$$
\mathrm{Y}=-2,679+0,171 \mathrm{X}_{1}+0,249 \mathrm{X}_{2}
$$

Persamaan regresi tersebut di atas dapat diinterpretasikan sebagai berikut:

1. Konstanta sebesar $-2,679$ berarti jika nilai net profit rate (NPR) dan ukuran perusahaan (SIZE) bernilai tetap atau 0 (nol), maka nilai koefisien respon laba adalah $-2,679$.

2. Koefisien regresi $X_{1}$ yang merupakan variabel net profit rate (NPR) sebesar 0,171 berarti jika variabel independen lain nilainya tetap dan net profit rate (NPR) mengalami kenaikan 1 satuan, maka koefisien respon laba (ERC) akan mengalami kenaikan sebesar 0,171. Koefisien bernilai positif artinya terjadi hubungan positif atau searah antara variabel independen dengan variabel dependen, semakin naik net profit rate (NPR) maka semakin naik koefisien respon laba (ERC) dan begitupun sebaliknya.

3. Koefisien regresi $\mathrm{X}_{2}$ yang merupakan variabel ukuran perusahaan (SIZE) sebesar 0,249 berarti jika variabel independen lain nilainya tetap dan ukuran perusahaan (SIZE) mengalami kenaikan 1 satuan, maka koefisien respon laba (ERC) akan mengalami kenaikan sebesar 0,249. Koefisien bernilai positif artinya terjadi hubungan positif atau searah antara variabel independen dengan variabel dependen, semakin naik ukuran perusahaan (SIZE) maka semakin naik koefisien respon laba (ERC) dan begitupun sebaliknya.

\subsubsection{Pengujian Hipotesis}

\subsubsection{Pengujian Regresi Secara Simultan (Uji F)}

Uji simultan (Uji F) dilakukan untuk menggambarkan seberapa jauh pengaruh variabel bebas atau variabel independen, yaitu tingkat laba bersih (NPR) dan ukuran perusahaan (SIZE) secara bersama-sama atau secara simultan dalam menerangkan variabel terikat atau variabel dependen, yaitu koefisien respon laba (ERC). Pengujian dilakukan dengan menggunakan tingkat signifikansi sebesar 0,05 $(=5 \%)$. Ketentuan penolakan dan penerimaan hipotesis adalah sebagai berikut:

1. Jika nilai signifikansi $\mathrm{F}>0,05$ atau Fhitung < Ftabel maka $\mathrm{H}_{0}$ diterima dan menolak $\mathrm{H}_{\mathrm{a}}$ (koefisien regresi tidak signifikan). Ini berarti bahwa secara bersama-sama seluruh variabel independen tidak mempunyai pengaruh yang signifikan terhadap variabel dependen.

2. Jika nilai signifikansi $\mathrm{F} \leq 0,05$ atau Fhitung $>$ Ftabel maka $\mathrm{H}_{0}$ ditolak dan menerima $\mathrm{H}_{\mathrm{a}}$ (koefisien regresi signifikan). Ini berarti bahwa secara bersama-sama seluruh variabel independen mempunyai pengaruh yang signifikan terhadap variabel dependen.

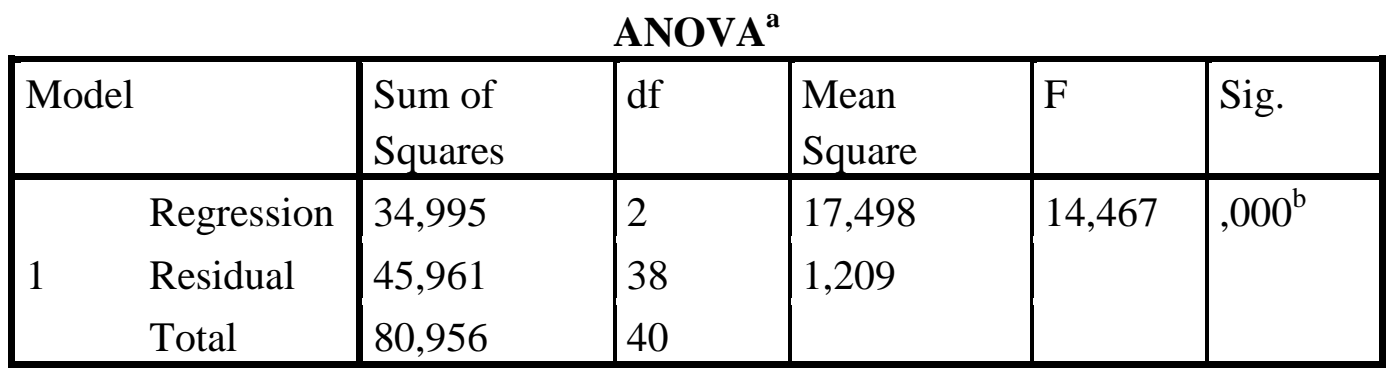

a. Dependent Variable: Ln_ERC

b. Predictors: (Constant), Ln_SIZE, Ln_NPR

Sumber: Data diolah peneliti 
Dari uji ANOVA atau uji $\mathrm{F}$ test tersebut, $\mathrm{F}_{\text {hitung }}$ sebesar 14,467 dengan tingkat signifikansi 0,000 karena nilai signifikansi kurang dari $0,05(0,000<0,05)$ maka $\mathrm{H}_{0}$ ditolak dan $\mathrm{H}_{\mathrm{a}}$ diterima, artinya ada pengaruh secara signifikan antara net profit rate (NPR) dan ukuran perusahaan (SIZE) secara simultan (bersama-sama) terhadap koefisien respon laba (ERC).

\subsubsection{Koefisien Determinasi $\left(\mathbf{R}^{2}\right)$}

Net Profit Rate (NPR) dan ukuran perusahaan (SIZE) secara simultan berpengaruh signifikan terhadap koefisien respon laba dapat dilihat dari nilai $\mathrm{R}^{2}$ dan $\mathrm{R}$-nya, yaitu:

Model Summary ${ }^{b}$

\begin{tabular}{|l|l|l|l|l|}
\hline Model & $\mathrm{R}$ & R Square & Adjusted R Square & $\begin{array}{l}\text { Std. Error of the } \\
\text { Estimate }\end{array}$ \\
\hline 1 &, $657^{\mathrm{a}}$ &, 432 &, 402 & 1,09977 \\
\hline
\end{tabular}

a. Predictors: (Constant), Ln_SIZE, Ln_NPR

b. Dependent Variable: Ln_ERC

Sumber: Data diolah peneliti

Nilai korelasi (R) sebesar 0,657 menunjukkan korelasi yang cukup kuat antara net profit rate (NPR) dan ukuran perusahaan (SIZE) dengan koefisien respon laba yaitu sebesar $65,7 \%$. Nilai $\mathrm{R}^{2}$ yang dihasilkan sebesar 0,432 berarti bahwa variabilitas koefisien respon laba dapat dijelaskan oleh net profit rate (NPR) dan ukuran perusahaan (SIZE) sebesar 43,2\% dan sisanya $100 \%-43,2 \%=56,8 \%$ dijelaskan oleh variabel lain diluar model.

\subsubsection{Pengujian Regresi Secara Parsial (Uji t)}

Uji t atau uji parsial dilakukan untuk menggambarkan seberapa jauh pengaruh masing-masing variabel independen, yaitu net profit rate (NPR) dan ukuran perusahaan (SIZE), secara parsial atau sendiri-sendiri dalam menerapkan variabel dependen, yaitu koefisien respon laba (ERC). Pengujian dilakukan dengan menggunakan tingkat signifikansi sebesar $0,05(\alpha=5 \%)$. Ketentuan penolakan atau penerimaan hipotesis adalah sebagai berikut:

1. Jika nilai signifikansi $>0,05$ maka $\mathrm{H}_{0}$ diterima dan menolak $\mathrm{H}_{\mathrm{a}}$ (koefisien regresi tidak signifikan). Ini berarti bahwa variabel independen tidak mempunyai pengaruh yang signifikan terhadap variabel dependen.

2. Jika nilai signifikansi $<0,05$ maka $\mathrm{H}_{0}$ ditolak dan menerima $\mathrm{H}_{\mathrm{a}}$ (koefisien regresi signifikan). Ini berarti bahwa variabel independen mempunyai pengaruh yang signifikan terhadap variabel dependen.

\begin{tabular}{|l|c|c|}
\hline \multicolumn{1}{|c|}{ Variabel Bebas } & t hitung & Sig. \\
\hline NPR & 1,228 & 0,063 \\
\hline SIZE & 2,341 & 0,000 \\
\hline
\end{tabular}

Sumber: Data diolah peneliti berikut:

Dari hasil uji di atas dapat diperoleh penjelasan untuk masing-masing variabel sebagai

1. Pengujian hipotesis net profit rate (NPR) terhadap koefisien respon laba Hipotesis:

$\mathrm{H}_{0} 1$ : Net profit rate (NPR) tidak berpengaruh terhadap koefisien respon laba.

$\mathrm{H}_{\mathrm{a}} 1 \quad$ : Net Profit Rate (NPR) berpengaruh terhadap koefisien respon laba.

Pada tabel diatas menunjukkan hasil pengujian secara parsial antara variabel net profit rate (NPR) terhadap koefisien respon laba. Dari tabel tersebut dapat diketahui nilai sig.t sebesar $0,063>0,05$ sehingga $\mathrm{H}_{\mathrm{a}} 1$ ditolak dan $\mathrm{H}_{0} 1$ diterima. Dengan demikian, return on investment (ROI) tidak berpengaruh signifikan terhadap koefisien respon laba.

2. Pengujian hipotesis ukuran perusahaan (SIZE) terhadap koefisien respon laba 
Hipotesis:

$\mathrm{H}_{0} 2$ : Ukuran perusahaan (SIZE) tidak berpengaruh terhadap koefisien respon laba.

$\mathrm{H}_{\mathrm{a}} 2$ : Ukuran perusahaan (SIZE) berpengaruh terhadap koefisien respon laba.

Pada tabel diatas menunjukkan hasil pengujian secara parsial antara variabel ukuran perusahaan (SIZE) terhadap koefisien respon laba. Dari tabel tersebut dapat diketahui nilai sig.t sebesar $0,000<0,05$ sehingga $\mathrm{H}_{0} 2$ ditolak dan $\mathrm{H}_{\mathrm{a}} 2$ diterima. Dengan demikian, ukuran perusahaan (SIZE) berpengaruh signifikan terhadap koefisien respon laba.

\subsection{Pembahasan}

\subsubsection{Pengaruh Tingkat Laba Bersih Terhadap Koefisien Respon Laba}

Tingkat laba bersih dalam penelitian ini diukur dengan net profit rate (NPR) yang merupakan perbandingan laba bersih setelah pajak dengan total aktiva yang dimiliki oleh perusahaan. Hipotesis pertama $\left(\mathrm{H}_{1}\right)$ menyatakan bahwa tingkat laba bersih berpengaruh signifikan terhadap koefisien respon laba. Berdasarkan uji hipotesis yang dilakukan diperoleh nilai koefisien regresi return on investment (ROI) sebesar 0,171 dengan tingkat signifikansi sebesar 0,063. Dengan koefisien regresi sebesar 0,171 menunjukkan bahwa tingkat laba bersih memiliki hubungan positif terhadap koefisien respon laba. Dengan tingkat signifikansi yang lebih besar dari yang disyaratkan yaitu 0,05 sehingga menunjukkan tingkat laba bersih tidak berpengaruh signifikan terhadap koefisien respon laba.

Adapun pengaruh positif antara tingkat laba bersih dengan koefisien respon laba dikarenakan bahwa apabila perusahaan melaporkan laba bersih semakin hari semakin meningkat, maka ERC akan semakin meningkat sehingga respon para investor juga semakit meningkat terhadap pengambilan keputusan dalam reaksi pasar saham. Tidak terdapat pengaruh signifikan dikarenakan kenaikan laba bersih tidak selalu linier dengan harga sahamnya. Harga saham itu juga dipengaruhi oleh profil risiko investor dan faktor eksternal, yaitu kondisi pasar. Dengan demikian, tingkat laba bersih berpengaruh positif dan tidak signifikan terhadap koefisien respon laba sehingga hipotesis pertama $\left(\mathrm{H}_{1}\right)$ tidak dapat diterima.

\subsubsection{Pengaruh Ukuran Perusahaan Terhadap Koefisien Respon Laba}

Ukuran perusahaan pada penelitian ini diukur dengan logaritma natural dari total aktiva dalam perusahaan (SIZE). Hipotesis kedua $\left(\mathrm{H}_{2}\right)$ menyatakan bahwa ukuran perusahaan berpengaruh signifikan terhadap koefisien respon laba. Berdasarkan uji hipotesis yang dilakukan diperoleh nilai koefisien regresi ukuran perusahaan (SIZE) sebesar 0,249 dengan tingkat signifikansi sebesar 0,000. Dengan koefisien regresi sebesar 0,249 menunjukkan bahwa ukuran perusahaan memiliki hubungan positif terhadap koefisien respon laba. Dengan tingkat signifikansi yang lebih kecil dari yang disyaratkan yaitu 0,05 sehingga menunjukkan ukuran perusahaan berpengaruh signifikan terhadap koefisien respon laba. Dengan demikian, ukuran perusahaan berpengaruh positif dan signifikan terhadap koefisien respon laba sehingga hipotesis kedua $\left(\mathrm{H}_{2}\right)$ dapat diterima. Hasil ini menunjukkan bahwa semakin besar ukuran perusahaan, maka perusahaan dianggap memiliki informasi yang lebih banyak dibandingkan dengan perusahaan kecil, yang konsekuensinya semakin informatif harga saham maka semakin kecil muatan informasi laba saat ini, semakin banyak ketersediaan sumber informasi pada perusahaan besar, akan meningkatkan koefisien respon laba dalam jangka panjang.

\subsubsection{Pengaruh Tingkat Laba Bersih Ukuran Perusahaan Terhadap Koefisien Respon Laba}

Berdasarkan hasil uji $\mathrm{F}$ didapatkan hasil $\mathrm{F}_{\text {hitung }}$ sebesar 14,467 dengan tingkat signifikansi 0,000 karena nilai signifikansi kurang dari $0,05(0,000<0,05)$, maka tingkat laba bersih yang diukur dengan net profit rate (NPR) dan ukuran perusahaan yang diukur dengan 
logaritma natural dari total aktiva perusahaan (SIZE) secara simultan berpengaruh signifikan terhadap koefisien respon laba.

\section{KESIMPULAN DAN SARAN}

\subsection{Kesimpulan}

1. Tingkat laba bersih yang diukur dengan net profit rate (NPR) berpengaruh positif tidak signifikan terhadap koefisien respon laba. Hal ini berarti tingkat laba bersih yang berupa perbandingan laba bersih setelah pajak dengan total aset tidak terlalu berperan penting dalam koefisien respon laba pada perusahaan manufaktur yang terdaftar di Bursa Efek Indonesia.

2. Ukuran perusahaan yang diukur dengan logaritma natural dari total aktiva perusahaan (SIZE) berpengaruh negatif signifikan terhadap koefisien respon laba. Hal ini berarti ukuran perusahaan (SIZE) memiliki peranan penting dalam koefisien respon laba pada perusahaan manufaktur yang terdaftar di Bursa Efek Indonesia.

3. Tingkat laba bersih yang diukur dengan net profit rate (NPR) dan ukuran perusahaan yang diukur dengan logaritma natural dari total aktiva perusahaan (SIZE) secara simultan berpengaruh signifikan terhadap koefisien respon laba.

\subsection{Saran}

1. Nilai $\mathrm{R}^{2}$ yang dihasilkan sebesar 0,432 berarti bahwa variabilitas nilai perusahaan dapat dijelaskan oleh net profit rate (NPR) dan ukuran perusahaan (SIZE) sebesar $43,2 \%$ dan sisanya $100 \%-43,2 \%=56,8 \%$ dijelaskan oleh variabel lain diluar model. Hal ini berarti masih ada variabel lain yang perlu diidentifikasi untuk menjelaskan koefisien respon laba. Variabel lain yang mungkin dapat mempengaruhi koefisien respon laba yaitu persistensi laba, kesempatan bertumbuh, resiko sistematik, struktur modal, dan pertumbuhan perusahaan.

2. Sebaiknya para investor dan calon investor hendaknya memperhatikan variabelvariabel yang berpengaruh signifikan terhadap koefisien respon laba. Hendaknya juga harus menyadari arti pentingnya publikasi laporan keuangan dan kualitas dalam pembuatan laporan tersebut.

3. Penelitian ini hanya dilakukan pada perusahaan manufaktur yang terdaftar di Bursa Efek Indonesia. Penelitian selanjutnya dapat melakukan penelitian dengan objek yang berbeda ataupun objek yang lebih luas dikarenakan setiap sektor ataupun industri perusahaan memiliki karakteristik yang berbeda.

4. Penelitian ini berdasarkan pada laporan tahunan dan dibatasi hanya pada periode 2013 sampai dengan 2016 sehingga belum menggambarkan kondisi keuangan perusahaan manufaktur secara menyeluruh.

\section{DAFTAR PUSTAKA}

Adiwiratama, Jundan, 2012. Pengaruh Informasi Laba, Arus Kas dan Size Perusahaan terhadap Return Saham (Studi Empiris pada Perusahaan Manufaktur yang Terdaftar di BEI). ISSN: 2089-3310, Jurnal Ilmiah Akuntansi dan Humanika, Vol.1, No. 2:(125).

Basuki, Agus Tri, dan Nano Prawoto. 2016. Analisis Regresi Dalam Penelitian Ekonomi \& Bisnis (Dilengkapi Aplikasi SPSS \& EVIEWS). Jakarta: PT. RajaGrafindo Persada.

Daniel, N. U., 2013. Pengaruh Ukuran Perusahaan, Leverage dan Likuiditas terhadap Luas Pengungkapan Laporan Keuangan (Studi Empiris pada Perusahaan Manufaktur yang Terdaftar di Bursa Efek Indonesia). Universitas Negeri Padang:(1-22).

Fitri, Laila, 2013. Pengaruh Ukuran Perusahaan, Kesempatan Bertumbuh, dan Profitabilitas terhadap Earnings Response Coefficient (Studi Empiris pada Perusahaan Manufaktur 
yang Terdaftar di Bursa Efek Indonesia (BEI) Tahun 2008-2011). Universitas Negeri Padang.

Herdirinandasari, Sherla Sherlia, 2016. Pengaruh Ukuran Perusahaan, Profitabilitas, dan Voluntary Disclosure terhadap Earnings Response Coefficient (ERC). ISSN : 24600585, Jurnal Ilmu dan Riset Akuntansi : Volume 5, Nomor 11 (1-19).

Keswari, Adjeng Nurdiyah. 2015. Pengaruh Ukuran Perusahaan, Ukuran KAP, Profitabilitas dan Leverage terhadap Earnings Response Coefficient. Universitas Muhammadiyah Surakarta:(1-15).

Khaksarian, Fatemeh, 2013. A Study on Relationship between Earnings Response Coefficient and Earnings Management: Evidence from Tehran Stock Exchange. Management Science Letters 3:(2549-2554).

Nofianti, Nana, 2014. Pengaruh Struktur Modal, Ukuran Perusahaan, dan Kebijakan Dividen terhadap Koefisien Respon Laba. Jurnal Etikonomi Vol. 13, No. 2:(118-147).

Paramita, Ratna Wijayanti Daniar, 2012. Pengaruh Leverage, Firm Size Dan Voluntary Disclosure Terhadap Earnings Response Coefficient (ERC) (Studi Pada Perusahaan Manufaktur Yang Terdaftar Di Bursa Efek Indonesia). ISSN: 2088-0944. Jurnal WIGA Vol. 2, No. 2:(103-118).

Rahayu, L. P. Agustina Kartika, dan Suaryana, I. G. N. Agung, 2015. Pengaruh Ukuran Perusahaan dan Risiko Gagal Bayar pada Koefisien Respon Laba. ISSN: 2302-8556. E-Jurnal Akuntansi Universitas Udayana Vol. 13, No. 2:(665-684).

Reeve, James M., Carl S. Warren, Jonathan E. Duchac, Ersa Tri Wahyuni, Gatot Soepriyanto, Amir Abadi Jusuf, and Chaerul D. Djakman. 2013. Pengantar Akuntansi Adaptasi Indonesia Buku 1. Jakarta: Indeks.

Santoso, Singgih. 2016. Menguasai SPSS 22 From Basic To Expert Skill. Jakarta: PT. Elex Media Komputindo.

Wahlen, James M., Jefferson P. Jones, and Donald P. Pagach. 2015. Intermediate Accounting: Reporting and Analysis. Mason, $\mathrm{OH}$ : South-Western Cengage Learning. 